\title{
Effect of different dry period lengths on milk production and somatic cell count in subsequent lactations in commercial Dutch dairy herds
}

\author{
W. Steeneveld, ${ }^{* 1}$ Y. H. Schukken, † A. T. M. van Knegsel,† and H. Hogeveen* $\S$ \\ ${ }^{*}$ Chair Group, Business Economics, Wageningen University, $6706 \mathrm{KN}$, Wageningen, the Netherlands \\ †Quality Milk Production Services, Cornell University, Ithaca, NY 14853 \\ $\ddagger$ Adaptation Physiology Group, Wageningen University, 6708 WD, Wageningen, the Netherlands \\ §Department of Farm Animal Health, Faculty of Veterinary Medicine, Utrecht University, $3584 \mathrm{CL}$, Utrecht, the Netherlands
}

\begin{abstract}
Shortening the dry period (DP) has been proposed as a management strategy to improve energy balance in early lactation. It is well known that both shortening and complete omission of the DP reduces milk production in the subsequent lactations. In most of these studies milk production data were obtained from planned animal experiments where cows were randomly assigned to DP length treatments, and cow management and diet composition did not differ among treatments. It may therefore be hypothesized that cows on commercial herds which apply a no-DP or short-DP-strategy, and support this by management adjustments, will have a less dramatic reduction in milk production. In this study, milk production and somatic cell count (SCC) following different DP lengths was investigated under commercial circumstances. Milk production of 342 cows (2,077 test-day records) was available from 5 Dutch commercial dairy herds which started a no DP-strategy for all cows. Test days of the year before applying the no-DP strategy are used as control (323 cows, 1,717 test-day records). Six other herds applied an individual cow approach and have different preplanned DP lengths within one herd. From these herds, information on 81 cows (482 test-day records) with a DP length between 0 and $20 \mathrm{~d}, 127$ cows (925 test-day records) with a DP length between 21 and $35 \mathrm{~d}$, and 143 cows $(1,075$ test-day records) with a DP length of more than $35 \mathrm{~d}$ was available. A generalized linear model incorporating an autoregressive covariance structure accounting for repeated test-day yields within cow was developed to estimate the daily yield (milk, fat and protein) and SCC of all cows. Applying no DP for all cows in the herd resulted in a reduction in postpartum milk production compared with within-herd control lactations (until 305 DIM) between 3.2 and $9.1 \mathrm{~kg} / \mathrm{d}$, which was a reduction of 12 and $32 \%$, respectively. For the 6 herds
\end{abstract}

Received October 22, 2012.

Accepted January 22, 2013.

${ }^{1}$ Corresponding author: wilma.steeneveld@wur.nl that applied an individual cow approach with different preplanned DP lengths, the cow-specific DP strategy was based on milk production and SCC approximately 2 mo before calving. Cows with a preplanned DP length ranging between 0 and $20 \mathrm{~d}$ had a reduction in postpartum milk production between 5.7 and $13 \mathrm{~kg} / \mathrm{d}$ compared with cows with a DP length of $>35$ d. Cows with a preplanned DP length ranging from 21 to $35 \mathrm{~d}$ had a numerically lower milk production (between 0.6 and $5.3 \mathrm{~kg} / \mathrm{d}$ ) than cows with a preplanned DP length of $>35 \mathrm{~d}$, but this difference was significant in only one herd. When corrected for milk yield, no difference in postpartum SCC for cows with different DP lengths was found.

Key words: continuous milking, short dry period, milk production, dairy cow

\section{INTRODUCTION}

Following parturition, high-producing dairy cows typically experience a negative energy balance (NEB). This NEB results from a quick increase in energy requirements for milk production while feed intake capacity in early lactation is limited. An NEB in early lactation is not only related to mobilization of body reserves and loss of $\mathrm{BW}$, but also to an increase in incidence of metabolic disorders (Grummer, 1993), infectious diseases (Collard et al., 2000), and reduced fertility (Butler, 2003). Shortening the dry period (DP) has been proposed as a management strategy to improve energy balance in early lactation (Grummer and Rastani, 2004). It is well known that both shortening and complete omission of the DP reduces milk production in the subsequent lactations; continuous milking results in significant production losses (Andersen et al., 2005; Klusmeyer et al., 2009; Mantovani et al., 2010). When shortening the DP length, a decrease in milk production is often reported, but this decrease is not always significant (Gulay et al., 2003; Pezeshki et al., 2007; Santschi et al., 2011a). When cows with a DP of 4 wk were compared with a traditional DP of 8 wk, milk production losses ranged from 1 to $13 \%$ 
(Annen et al., 2004; Pezeshki et al., 2007). When the DP was omitted, milk production losses amount up to $24 \%$ compared with cows with a DP of 8 wk (Andersen et al., 2005; Klusmeyer et al., 2009; Mantovani et al., 2010). From these studies it can be concluded that reducing DP length decreases milk yield in the subsequent lactations, though several remarks should be made related to this conclusion. First, in most studies omitting the DP increases milk protein content (Andersen et al., 2005; de Feu et al., 2009). Second, most studies only reported milk production effects during a restricted period postcalving (ranging from 35 to 294 DIM; Andersen et al., 2005; Klusmeyer et al., 2009). Third, the additional milk yield before calving was only reported in few studies (Rastani et al., 2005; Mantovani et al., 2010; Schlamberger et al., 2010). Fourth, the results on milk production were obtained on planned animal experiments on research herds where cows were randomly assigned to DP length treatments, and cow management and diet composition did not differ among treatments (Annen et al., 2004; Andersen et al., 2005). It can be hypothesized that, on commercial herds, farmers can apply an individual cow approach during the decision process of planning DP lengths, and take specific cow characteristics, such as milk production level, persistency, age, and SCC, into account. Furthermore, in practice, shortening or omitting the DP can be accompanied by other cow management and diet adjustments, which have not been studied in planned animal experiments on research herds until now. It may therefore be hypothesized that cows on commercial herds which apply a no-DP strategy and accompany this with management adjustments will have a less dramatic reduction in milk production.

The aim of this study is to evaluate production ( $\mathrm{kg}$ of milk, fat, and protein) and SCC following different DP lengths under commercial circumstances. This study used data from commercial Dutch dairy herds who either started to apply the no-DP strategy for all cows ( 5 herds) or applied an individual cow approach, and thus have different preplanned DP lengths within one herd (6 herds).

\section{MATERIALS AND METHODS}

\section{Herds}

In 2010 an advertisement was placed in a Dutch farmers magazine seeking farmers to join a study group concerning the practical application of a no- or shorterDP strategy. At the first meeting 32 farmers were present, ranging from farmers who are interested in applying a shorter- or no-DP strategy to farmers who have applied this strategy for years. Two months after the meeting, farmers who actually apply no- or shorter-DP strategy were contacted. Only the farmers applying no DP quite recently $(\mathrm{n}=5)$ and the herds applying an individual cow approach with different preplanned DP lengths were selected $(\mathrm{n}=6)$ for data collection. Five herds (herds A-E) started between October 2010 and April 2011 voluntarily with an omission of the DP for all cows in their herd (no-DP strategy; Table 1). Six herds (herds $\mathrm{F}-\mathrm{K}$ ) voluntarily applied an individual cow approach and set different preplanned DP lengths ranging from 0 to $77 \mathrm{~d}$ within one herd. Decisions on the length of the DP on herds $\mathrm{F}$ through $\mathrm{K}$ were different between herds. On herd F, the intention was to give all cows a DP of $4 \mathrm{wk}$, but adjustments to this were made based on the milk production level of the cow approximately 2 mo before the expected calving date. On herds $\mathrm{G}, \mathrm{H}$, and $\mathrm{K}$, only cows with high-milk production and low SCC approximately 2 mo before the expected calving date received a DP length less than $20 \mathrm{~d}$; all other cows received DP lengths of at least 4 wk. On herds I and J, the level of milk production approximately 2 mo before the expected calving date was the criteria for the choice of the DP length. Herd size ranged from 46 to 160 cows; all cows were of mixed breed (herd A) or of the Holstein-Friesian breed (herds $\mathrm{B}-\mathrm{K}$ ). Cows were housed on a bedded pack (herd A) or in freestall barns with cubicles (herds B-K). Herds $\mathrm{A}$ and D were milking with an automatic milking system, the other herds were milking twice a day with a conventional milking system (except herd E, which milked 3 times a day). Herd C was fed a TMR, whereas the other herds fed a partial mixed ration and had an individual cow-accessed concentrate feeding system. The rations differed considerably between the herds, with varying amounts and ingredients. The amount of concentrates varied between a maximum of 5.5 (herd B) and 13 (herd A) kg per day. Individual cow milk yield and composition (fat, protein and SCC) was measured within a 4-, 5-, or 6-week interval. Data on milk recording and calving dates were obtained from the Dutch national milk recording system (CRV, Arnhem, the Netherlands). Dates of drying-off (or lack thereof) were provided by the farmers.

\section{Herds Eliminating DP for all Cows}

Data Editing. From the 5 herds (A-E) that started the no-DP strategy, data from 443 lactations (parity $\geq 2$ ) were available after the starting date until April 1,2012 . As only one lactation after a no-DP-strategy was analyzed, the second lactation of a cow after starting the no-DP strategy was excluded $(\mathrm{n}=44)$. Herd D stopped applying the no-DP strategy in November 2011, and therefore lactations started after Novem- 
Table 1. Overview of the herds and their applied dry period (DP) length

\begin{tabular}{|c|c|c|c|c|c|c|c|c|c|}
\hline Herd & $\begin{array}{c}\text { Herd } \\
\text { size (no.) }\end{array}$ & \multicolumn{3}{|c|}{ Average $305-\mathrm{d}$ production } & $\begin{array}{l}\text { DP length } \\
\text { (d) }\end{array}$ & Starting date & \multicolumn{3}{|c|}{ No. of cows (no. of test-days) per DP length } \\
\hline $\mathrm{B}$ & 125 & 7,708 & 4.43 & $3.61^{2}$ & 0 & April 2011 & $87(437)$ & & $84(383)$ \\
\hline $\mathrm{C}$ & 82 & 7,658 & 4.79 & $3.70^{2}$ & 0 & January 2011 & $58(317)$ & & $53(294)$ \\
\hline $\mathrm{D}$ & 89 & 9,788 & 4.47 & $3.55^{2}$ & 0 & March 2011 & $41(344)$ & & $39(342)$ \\
\hline $\mathrm{H}$ & 68 & 8,711 & 4.73 & $3.76^{3}$ & $0-68$ & January 2011 & $7(56)$ & $15(89)$ & $22(136)$ \\
\hline I & 62 & 10,861 & 4.30 & $3.53^{3}$ & $22-71$ & March 2010 & & $20(195)$ & $39(392)$ \\
\hline $\mathrm{J}$ & 46 & 9,828 & 4.49 & $3.63^{3}$ & $0-63$ & November 2010 & $2(11)$ & $9(67)$ & $26(191)$ \\
\hline $\mathrm{K}$ & 107 & 7,024 & 5.20 & $3.61^{3}$ & $0-71$ & September 2011 & $43(229)$ & $14(83)$ & $20(100)$ \\
\hline
\end{tabular}

${ }^{1}$ For herds A to E the no DP implies a DP between 0 and $10 \mathrm{~d}$, for herds F to K the no DP implies a DP between 0 and $20 \mathrm{~d}$.

${ }^{2}$ Average from the last test-day before the herd started with omission of the DP.

${ }^{3}$ Average from the test-day in April 2012.

ber 1, 2011 were excluded $(\mathrm{n}=20)$. Herds with an automatic milking system (herds $\mathrm{A}$ and $\mathrm{D}$ ) dried-off some cows because their milk yield was too low, which resulted in failed milkings. If the DP of these cows was longer than $10 \mathrm{~d}$, cows were excluded from the data set $(\mathrm{n}=37)$. The final number of cows with a no-DP strategy was 342 . From these cows only test-day records until d 305 in lactation were selected $(\mathrm{n}=2,077$ test days). All farmers indicated that in the year preceding the start of applying a no-DP-strategy all cows had a traditional DP of at least $45 \mathrm{~d}$. Therefore, all cows (parity $\geq 2$ ) calved during the year before the start of a no-DP strategy were defined as within-herd control lactations. The final number of cows in the data set with a conventional DP length was 323. From these cows only test-day records until d 305 in lactation were selected ( $\mathrm{n}=1,717$ test-days). Cows with no DP had a much longer lactation; nevertheless, a cut-off of 305 $\mathrm{d}$ was used to compare the production of cows with no DP to those with a conventional DP length.

Statistical Analyses. Statistical analyses were carried out to compare lactation curves (for milk, fat, and protein; all in $\mathrm{kg} / \mathrm{d}$ ) of the cows with no-DP strategy and control cows using SAS (PROC MIXED) version 9.2 (SAS Institute Inc., Cary, NC). The shape of the lactation curve was modeled using the Wilmink model and included DIM and the exponential DIM ${ }^{-0.05}$ (Wilmink, 1987). Model 1 also included parity (2 or $\geq 3$ ), DP category (no-DP and conventional DP), herd (A-E), and calving season (January-March, April-June, JulySeptember, and October-December) as fixed effects. An autoregressive covariance structure accounting for repeated test-day yields (coded 1 to 10) within a lactation of a cow was incorporated. All variables were analyzed using a backward stepwise procedure. Only variables at $P \leq 0.05$ in the Wald test were retained in the model. Herd and calving season were forced into the model. The initial model was

$$
\begin{aligned}
y_{i j k} & =\beta_{0}+\beta_{1, m} \text { parity }+\beta_{2} \mathrm{DIM}_{i j k}+\beta_{3} \exp { }^{\left(-0.05 D I M_{i j k}\right)} \\
& +\beta_{4, n} \text { season }+\beta_{5, o} \text { herd }+\beta_{6, p} \mathrm{DP}+\rho \varepsilon_{i j k},
\end{aligned}
$$

(model 1)

where $y$ is the yield of cow $i$ in DP category $j$ on test day $k ; \beta_{1, m}$ is the effect of $m$ th parity; $\beta_{2}$ is the effect of DIM; $\beta_{3}$ is the effect of Wilmink's correction; $\beta_{4, n}$ is the effect of the $n$th calving season; $\beta_{5, o}$ is the effect of the oth herd; and $\beta_{6, p}$ is the effect of the $p$ th DP category (no DP or conventional). The term $\rho \varepsilon_{i j k}$ is a complex error term consisting of 2 components, $\rho$ is the withincow correlation (assuming auto-correlation) and $\varepsilon_{i j k}$ is the random error term. Biological plausible interaction terms were also included (not shown in model 1). Estimated intercepts and regression coefficients for DIM and $\mathrm{DIM}^{-0.05}$ obtained for the Wilmink function were used for fitting the lactation curve for the 2 groups of cows (no DP and conventional). Least squares means were calculated to compare the yield of the 2 groups of cows.

The SCC was log-transformed (lnSCC) and analyzed with model 2 using SAS (PROC MIXED). The lnSCC was the dependent variable, and parity ( 2 or $\geq 3$ ), stage of lactation (10 stages of each $30 \mathrm{~d}$ ), the DP category (no DP or conventional), herd (A-E), test-day milk yield, and calving season (January-March, April-June, July-September, and October-December) were the independent variables. An autoregressive covariance structure accounting for repeated test-day yields within a lactation of a cow was incorporated. All variables were analyzed using a backward stepwise procedure. Only variables at $P \leq 0.05$ in the Wald test were retained 
in the model. Herd and calving season were forced into the model. The initial model was

$$
\begin{gathered}
y_{i j k}=\beta_{0}+\beta_{1, m} \text { parity }+\beta_{2, n} \text { stage }_{i j k}+\beta_{3, o} \text { season } \\
+\beta_{4, p} \text { herd }+\beta_{5} \text { milkyield }+\beta_{6, q} \mathrm{DP}+\rho \varepsilon_{i j k},(\text { model } 2)
\end{gathered}
$$

where $y$ is the $\operatorname{lnSCC}$ of cow $i$ in DP category $j$ on test day $k ; \beta_{1, m}$ is the effect of $m$ th parity; $\beta_{2, n}$ is the effect of $n$th stage of lactation; $\beta_{3, o}$ is the effect of the oth calving season; $\beta_{4, p}$ is the effect of the $p$ th herd; $\beta_{5}$ is the effect of the test-day milk yield; and $\beta_{6, q}$ is the effect of the $q$ th DP category (no DP or conventional). The term $\rho \varepsilon_{i j k}$ is a complex error term consisting of 2 components, $\rho$ is the within cow correlation (assuming auto-correlation) and $\varepsilon_{i j k}$ is the random error term. Biological plausible interaction terms were also included (not shown in model 2). Least squares means were calculated to compare the $\ln \mathrm{SCC}$ of the 2 groups of cows. Goodness of fit of both models was assessed by judging the residuals. The residuals were plotted against the fitted values and judged for peculiarities (Dohoo et al., 2003).

\section{Herds with Preplanned DP Length}

Data Editing. The 6 herds $(\mathrm{F}-\mathrm{K})$ that applied an individual cow approach with different preplanned DP lengths were followed during different periods. In total, 435 lactations (parity $\geq 2$ ) were recorded from the starting date until April 1, 2012. Cows were followed for 1 lactation, and therefore the second lactation after the starting date of a cow was excluded $(\mathrm{n}=73)$. Cows with DP longer than $80 \mathrm{~d}(\mathrm{n}=11)$ were excluded. The final number of cows with preplanned DP lengths was 351 . From these cows only test-days until d 305 in lactation were selected ( $\mathrm{n}=2,482$ test-days). Cows with no DP would have a much longer lactation; nevertheless, a cut off of $305 \mathrm{~d}$ was used to compare the production of cows with no DP to those with cows with a normal DP length. Results of analyses showed that production of cows with DP lengths of 0,1 to 10 , and 11 to $20 \mathrm{~d}$ dry did not differ from each other. Therefore, the DP lengths were classified into 0 to $20 \mathrm{~d}$ dry, 21 to $35 \mathrm{~d}$ dry, and $>35 \mathrm{~d}$ dry. Test-day information from the previous lactation was available for all calved cows. This information was used to determine cow characteristics from the previous lactation. Defined cow characteristics were parity, DIM, 305-d milk production, lactation production, average $\ln \mathrm{SCC}$ of the lactation, $\operatorname{lnSCC}$ at the test day closest to $56 \mathrm{~d}$ before calving, daily milk yield at the test day closest to $56 \mathrm{~d}$ before calving, fat percentage at the test day closest to $56 \mathrm{~d}$ before calving, and protein percentage at the test day closest to $56 \mathrm{~d}$ before calving. Data preparation was performed using SAS version 9.2 (SAS Institute Inc.).

Statistical Analyses. Statistical analyses were carried out to compare lactation curves (for milk, fat, and protein; all in $\mathrm{kg} / \mathrm{d}$ ) of the cows with different preplanned DP lengths. The same model and procedure was used as for comparing cows with and without a DP (model 1), except that extra covariates on characteristics of the previous lactation were included (parity, DIM, 305-d milk production, lactation production, daily milk yield at the test day closest to $56 \mathrm{~d}$ before calving, fat percentage at the test day closest to $56 \mathrm{~d}$ before calving, and protein percentage at the test day closest to $56 \mathrm{~d}$ before calving). The initial model was

$$
\begin{aligned}
y_{i j k} & =\beta_{0}+\beta_{1, m} \text { parity }+\beta_{2} \mathrm{DIM}_{i j k}+\beta_{3} \exp { }^{\left(-0.05 \mathrm{DIM}_{i j k}\right)} \\
& +\beta_{4, n} \text { season }+\beta_{5, o} \text { herd }+\beta_{6, p} \text { DPCAT }+\beta_{7, q} \text { parity_prev } \\
& +\beta_{8} \text { DIM_prev }+\beta_{9} \text { milk305_prev }+\beta_{10} \text { milklact_prev } \\
& +\beta_{11} \text { milk56 }+\beta_{12} \text { fat } 56+\beta_{13} \text { protein } 56+\rho \varepsilon_{i j k},
\end{aligned}
$$

(model 3)

where $y$ is the yield of cow $i$ in DP category $j$ on test day $k ; \beta_{1, m}$ is the effect of $m$ th parity; $\beta_{2}$ is the effect of DIM; $\beta_{3}$ is the effect of Wilmink's correction; $\beta_{4, n}$ is the effect of the $n$th calving season; $\beta_{5, o}$ is the effect of the oth herd; $\beta_{6, p}$ is the effect of the $p$ th DP category $(0-20$, $21-35$, and $>35 \mathrm{~d}$ dry); $\beta_{7, q}$ is the effect of the qth parity of the previous lactation; $\beta_{8}$ is the effect of DIM in the previous lactation; $\beta_{9}$ is the effect of the $305-\mathrm{d}$ milk production of the previous lactation; $\beta_{10}$ is the effect of the total milk production in the previous lactation; $\beta_{11}$ is the effect of the daily milk yield at the test day closest to 56 before calving; $\beta_{12}$ is the effect of the fat percentage at the test day closest to $56 \mathrm{~d}$ before calving; and $\beta_{13}$ is the effect of the protein percentage at the test day closest to $56 \mathrm{~d}$ before calving. The term $\rho \varepsilon_{i j k}$ is a complex error term consisting of 2 components, $\rho$ is the within cow correlation (assuming auto-correlation) and $\varepsilon_{i j k}$ is the random error term. Biological plausible interaction terms were also included (not shown in model 3). Estimated intercepts and regression coefficients for DIM and DIM ${ }^{-0.05}$ obtained by the Wilmink function were used to fit the lactation curve for the 3 groups of cows $(0-20,21-35$, and $>35$ d dry). Least squares means were calculated to compare the yield of the 3 groups of cows.

To compare the SCC of the cows with different preplanned DP lengths, the same model and procedure was used as for comparing cows with and without a DP, except the extra covariates on characteristics of the previous lactation were included. The initial model was 


$$
\begin{gathered}
y_{i j k}=\beta_{0}+\beta_{1, m} \text { parity }+\beta_{2, n} \text { stage }_{i j k}+\beta_{3, o} \text { season } \\
+\beta_{4, p} \text { herd }+\beta_{5, q} \text { DPCAT }+\beta_{6} \text { milkyield } \beta_{7, r} \text { parity_prev } \\
+\beta_{8} \text { DIM_prev }+\beta_{9} \text { milk305_prev }+\beta_{10} \text { milklact_prev } \\
+\beta_{11} \operatorname{lnSCC}+\beta_{12} \operatorname{lnSCC} 56+\beta_{13} \text { milk } 56+\beta_{14} \text { fat } 56 \\
+\beta_{15} \text { protein } 56+\rho \varepsilon_{i j k},(\text { model } 4)
\end{gathered}
$$

where $y$ is the $\operatorname{lnSCC}$ of cow $i$ in DP category $j$ on test day $k ; \beta_{1, m}$ is the effect of $m$ th parity; $\beta_{2, n}$ is the effect of $n$th stage of lactation; $\beta_{3, o}$ is the effect of the oth calving season; $\beta_{4, p}$ is the effect of the $p$ th herd; $\beta_{5, q}$ is the effect of the $q$ th DP category $(0-20,21-35$, and $>35 \mathrm{~d}$ dry); $\beta_{6}$ is the effect of test-day milk yield; $\beta_{7, r}$ is the effect of the $r$ th parity of the previous lactation; $\beta_{8}$ is the effect of DIM in the previous lactation; $\beta_{9}$ is the effect of the $305-\mathrm{d}$ milk production of the previous lactation; $\beta_{10}$ is the effect of the total milk production in the previous lactation; $\beta_{11}$ is the effect of the average $\operatorname{lnSCC}$ of the previous lactation; $\beta_{12}$ is the effect of the $\operatorname{lnSCC}$ at the test day closest to $56 \mathrm{~d}$ before calving; $\beta_{13}$ is the effect of the milk yield at the test day closest to $56 \mathrm{~d}$ before calving; $\beta_{14}$ is the effect of the fat percentage at the test day closest to $56 \mathrm{~d}$ before calving; and $\beta_{15}$ is the effect of the protein percentage at the test day closest to $56 \mathrm{~d}$ before calving. The term $\rho \varepsilon_{i j k}$ is a complex error term consisting of 2 components, $\rho$ is the within cow correlation (assuming auto-correlation) and $\varepsilon_{i j k}$ is the random error term. Biological plausible interaction terms were also included (not shown in model 4). Least squares means were calculated to compare the $\operatorname{lnSCC}$ of the 3 groups of cows. Goodness of fit for both models was assessed by judging the residuals. The residuals were plotted against the fitted values and judged for peculiarities (Dohoo et al., 2003).

\section{RESULTS}

\section{Herds Eliminating DP for all Cows}

In Table 2 the average test-day yield (milk, fat, and protein) before and after calving for cows with no DP or a conventional DP length is presented for the 5 herds that started the no-DP strategy for all cows. Average milk yield in the last $56 \mathrm{~d}$ before the start of the second lactation varied between 12.9 (herd D) and $14.5 \mathrm{~kg} / \mathrm{d}$ (herd B), and the average test-day milk yield in the last $56 \mathrm{~d}$ before the start of older lactations $(\geq 3)$ varied between 11.3 (herds $\mathrm{C}$ and E) and $14.3 \mathrm{~kg} / \mathrm{d}$ (herd A). Milk fat percentage in the last $56 \mathrm{~d}$ before the start of the second lactation varied between 4.52 (herd E) and 5.64 (herd C), whereas milk protein percentage varied between 3.63 (herd E) and $4.57 \%$ (herd B). In the 305 $\mathrm{d}$ after calving, cows with no DP had a lower milk yield than cows with a conventional DP length, although this difference was small for older cows in herd $\mathrm{C}(0.1 \mathrm{~kg} / \mathrm{d})$. For all herds, milk protein percentage postcalving was higher for cows with no DP compared with cows with a conventional DP length. For almost all herds, milk fat percentage was higher for cows with no DP compared with cows with a conventional DP length (except cows of parity $>2$ in herds $\mathrm{A}$ and $\mathrm{B}$ ).

In Table 3 the coefficient estimates of the final model for estimating milk, fat, and protein production during 1 till 305 DIM, subsequent to no or a conventional DP length, are presented. Cows with no DP produced $9.7 \mathrm{~kg} / \mathrm{d}$ less milk, $246 \mathrm{~g} / \mathrm{d}$ less fat, and $190 \mathrm{~g} / \mathrm{d}$ less protein from 1 to 305 DIM compared with cows with a conventional DP length, as illustrated by Figure 1 . Total 305-d milk production of young cows (parity 2) with no DP was $7,939 \mathrm{~kg}$, whereas young cows with a conventional DP length had a 305-d milk production of 9,740 kg. Total 305-d milk production of older cows (parity >2) with no DP was 8,249 kg, whereas older cows with a conventional DP length had a 305-d milk production of $10,012 \mathrm{~kg}$. The peak production for young cows with no DP was $30.7 \mathrm{~kg} / \mathrm{d}$ (at d 54), whereas for young cows with a conventional DP length the peak production was $39.3 \mathrm{~kg} / \mathrm{d}$ (at d 59). The peak production for older cows with no DP was $34.4 \mathrm{~kg} / \mathrm{d}$ (at d 50), whereas older cows with a conventional DP length the peak production was $41.5 \mathrm{~kg} / \mathrm{d}$ (at d 56). Young cows with no DP have a flatter lactation curve than older cows with no DP, which can also be seen from the interaction term DP length with parity (Table 3 ). In Figure 2 the daily milk yield per herd for cows with no DP and cows with a conventional DP length is presented. For all 5 herds milk production with no DP was lower $(P$ $<0.01$ ) compared with conventional DP, ranging from 3.2 (herd B) to $9.1 \mathrm{~kg} / \mathrm{d}$ (herd E) less milk per cow. Both fat and protein production were greater with a conventional DP length compared with no DP (Figure 3 ). Estimated total fat and protein production in $305 \mathrm{~d}$ for cows with no DP was 382 and $318 \mathrm{~kg}$, respectively, whereas cows with a conventional DP length produced $464 \mathrm{~kg}$ of fat and $351 \mathrm{~kg}$ of protein.

Parity, stage of lactation, season, herd, and test-day milk yield were included in the final model to explain SCC subsequent to no or conventional DP length (Table 4). The variable DP length was not significant in this final model, implying that SCC was not different among cows with no DP and conventional DP length.

\section{Herds with Preplanned DP Length}

Table 5 shows that heifers (herds G, H, and K), cows with a relatively high daily milk yield $56 \mathrm{~d}$ before expected calving date (herds F, G, H, J, and K), and cows 
Table 2. Average production per day before and after calving for cows with no dry period (DP) or cows with a conventional (conv) DP length

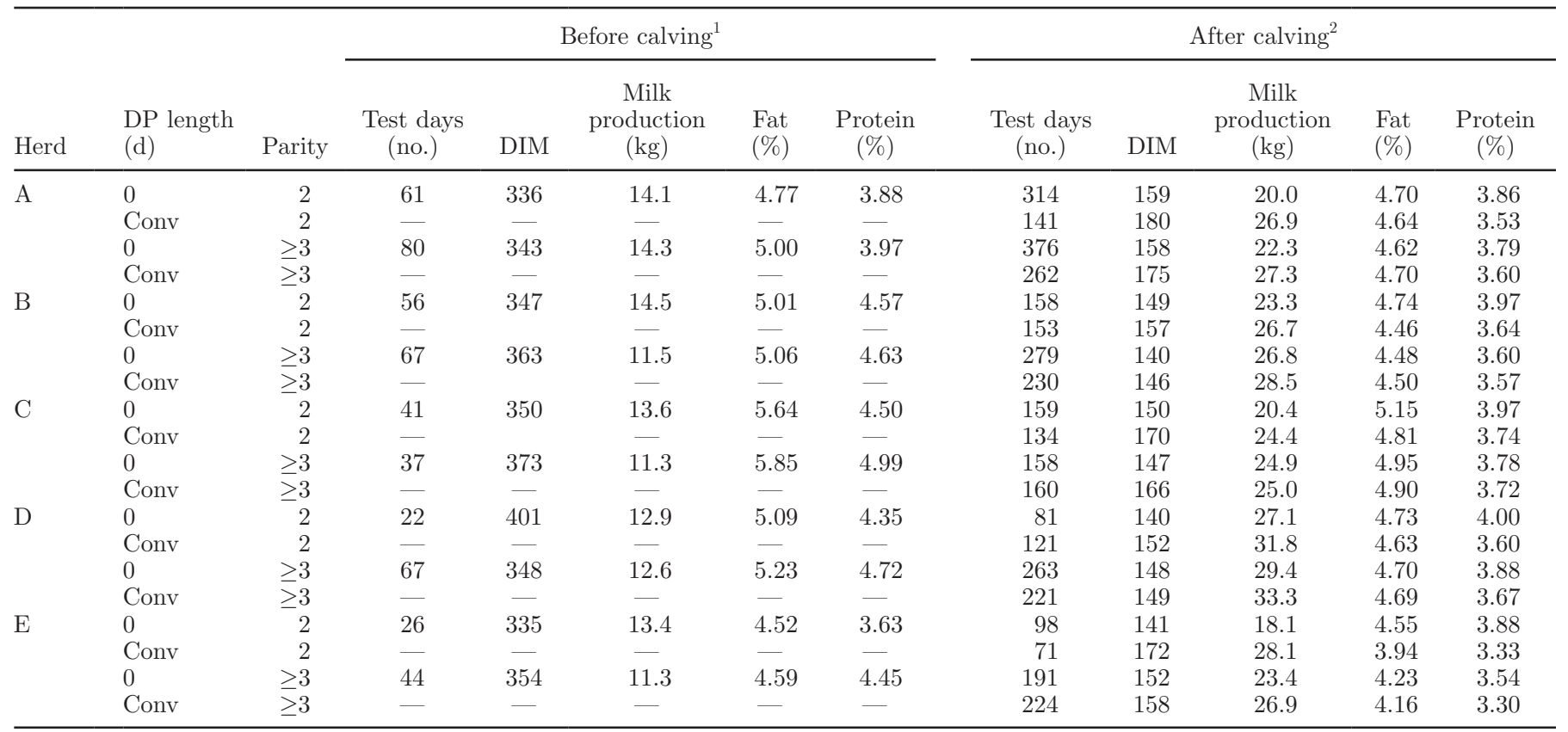

${ }^{1}$ Information based on test days in the last $56 \mathrm{~d}$ before calving, which is only applicable for the cows with no DP.

${ }^{2}$ Information based on test days until 305 DIM.

with a low SCC (herds $\mathrm{G}, \mathrm{H}$, and $\mathrm{K}$ ) were assigned to a shorter DP length (0-20 or 21-35 d dry). Older cows (parity $>2$; herds $\mathrm{H}$ and $\mathrm{K}$ ), cows with a low daily milk yield $56 \mathrm{~d}$ before the expected calving date (all herds), and cows with a high SCC $56 \mathrm{~d}$ before expected calving date (herds G, I, and K) received a preplanned DP of at least $35 \mathrm{~d}$.

In Table 6 the coefficient estimates of the final model for estimating milk, fat, and protein production subsequent to different preplanned DP length are presented. Cows with a DP length ranging from 0 to $20 \mathrm{~d}$ produced $8.20 \mathrm{~kg} / \mathrm{d}$ less milk, $263.26 \mathrm{~g} / \mathrm{d}$ less fat, and $217.82 \mathrm{~g} / \mathrm{d}$ less protein compared with cows with a DP length of more than $35 \mathrm{~d}$, as illustrated by Figure 4 . Total 305-d milk production of cows with a DP ranging from 0 to $20 \mathrm{~d}$ was $5,682 \mathrm{~kg}$, whereas cows with a DP length ranging from 21 to $35 \mathrm{~d}$ had a 305-d milk production of $7,587 \mathrm{~kg}$. Total 305-d milk production of cows with a DP length longer than $35 \mathrm{~d}$ was $8,436 \mathrm{~kg}$. The peak production for cows with a DP length ranging from 0 to $20 \mathrm{~d}$ was $27.1 \mathrm{~kg} / \mathrm{d}$ (at d 35), whereas for cows with a DP length ranging from 21 to $35 \mathrm{~d}$ the peak production was $34.2 \mathrm{~kg} / \mathrm{d}$ (at d 43). The peak production for cows with a DP length of at least $35 \mathrm{~d}$ was $37.8 \mathrm{~kg} / \mathrm{d}$ (at d 47). On all herds, milk production postpartum was lower for cows with a DP length ranging from 0 to $20 \mathrm{~d}$ compared with the milk production of cows with a longer DP length $(P<0.01$; Figure 5$)$. For herd K, milk yield for cows with a DP length ranging from 0 to
$20 \mathrm{~d}$ was $5.7 \mathrm{~kg} / \mathrm{d}$ lower than for cows with a DP length of at least $35 \mathrm{~d}$. For herds $\mathrm{H}$ and J, milk yield for cows with a DP length ranging from 0 to $20 \mathrm{~d}$ was 11.6 and $13 \mathrm{~kg} / \mathrm{d}$ lower compared with cows with a DP length of at least $35 \mathrm{~d}$. On all herds, milk production postpartum for cows with a DP length ranging from 21 to $35 \mathrm{~d}$ was lower than milk production of cows with a DP length longer than $35 \mathrm{~d}$, but only in herd I was the difference significant $(P<0.01)$. Both fat and protein production were highest for cows with a DP length $>35 \mathrm{~d}$ (Figure 6). Estimated total fat and protein production over 305 $\mathrm{d}$ for cows with a DP length of 0 to $20 \mathrm{~d}$ were 287 and $221 \mathrm{~kg}$, respectively, whereas cows with a DP length of at least $35 \mathrm{~d}$ produced $416 \mathrm{~kg}$ of fat and $347 \mathrm{~kg}$ of protein.

Parity, stage of lactation, season, herd, test-day milk yield, average SCC of the previous lactation, SCC at the test day closest to $56 \mathrm{~d}$ before calving, and the interaction parity with stage of lactation were included in the final model to explain SCC subsequent to different preplanned DP lengths (Table 4). The variable DP length was not significant in this final model, implying that SCC was not different among cows with different preplanned DP lengths.

\section{DISCUSSION}

In this study, postpartum milk yield subsequent to no DP was estimated based on data of 5 commercial 
Table 3. Coefficient estimates $(\beta)$ of the mixed model for test-day milk yield $(\mathrm{kg} / \mathrm{d})$, fat $(\mathrm{g} / \mathrm{d})$, and protein $(\mathrm{g} / \mathrm{d})$ in the lactation $(1-305 \mathrm{DIM})$ subsequent to no dry period (DP) or a conventional DP length

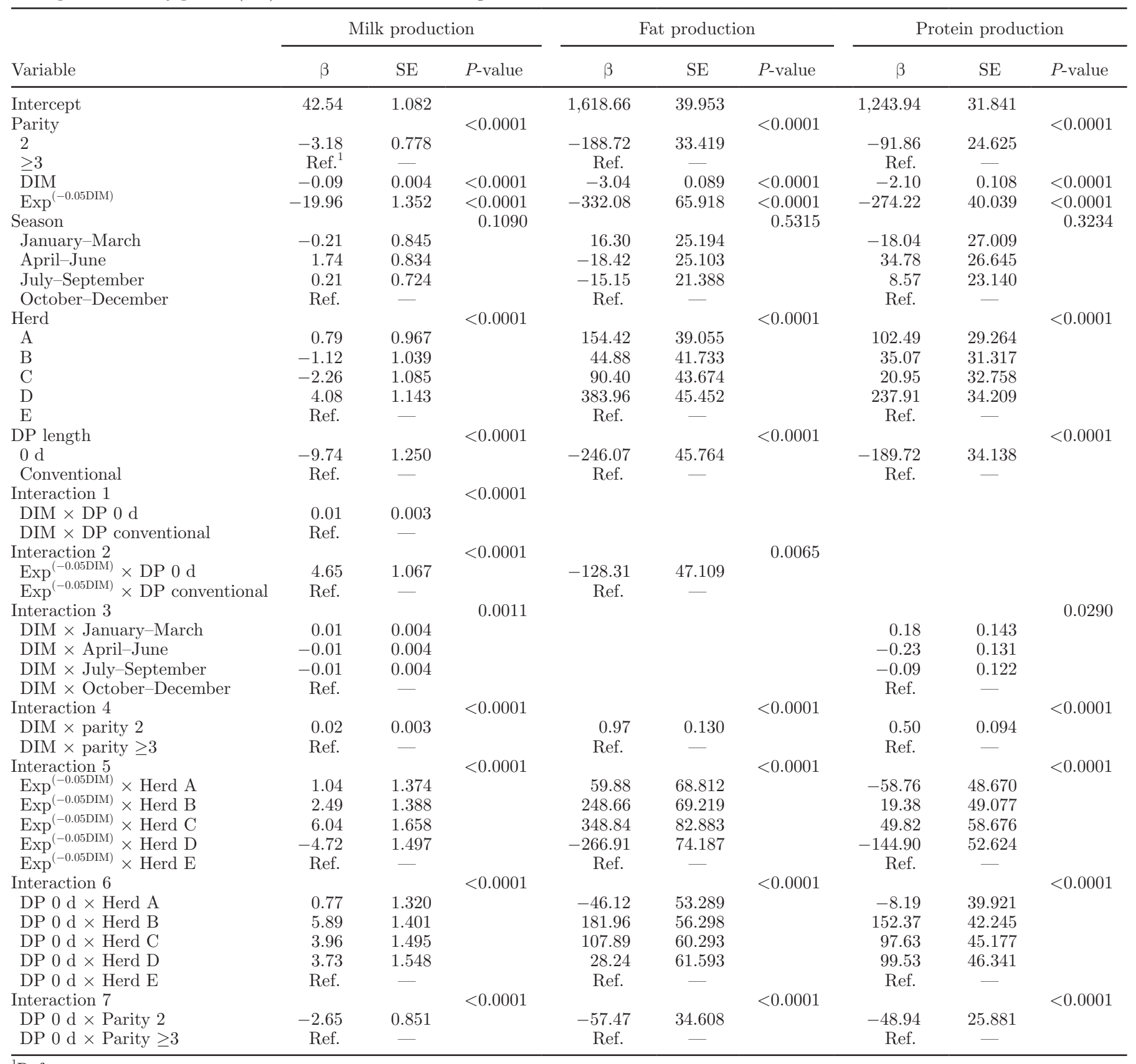

${ }^{1}$ Reference group.

Dutch dairy herds (A-E). Applying no DP for all cows in the herd resulted in a reduction in milk production compared with within-herd control lactations (1-305 DIM) between 3.2 and $9.1 \mathrm{~kg} / \mathrm{d}$ (Figure 2), which was a reduction of 12 and $32 \%$, respectively. These results are comparable with findings from studies based on planned animal experiments where cows were randomly assigned to no DP or a conventional DP length. Both Andersen et al. (2005) and de Feu et al. (2009) re- ported a reduction in milk production of 22 and $16 \%$, respectively. These studies measured however the effects during a restricted period postcalving ( 5 and 12 wk postpartum, respectively). Mantovani et al. (2010) reported a reduction in milk production of $24 \%$ during 1 to $305 \mathrm{~d}$ postpartum subsequent to no DP, with a limited data set of 17 cows. The commercial herds A through E made management adjustments, especially ration adjustments, to try to keep the milk production 


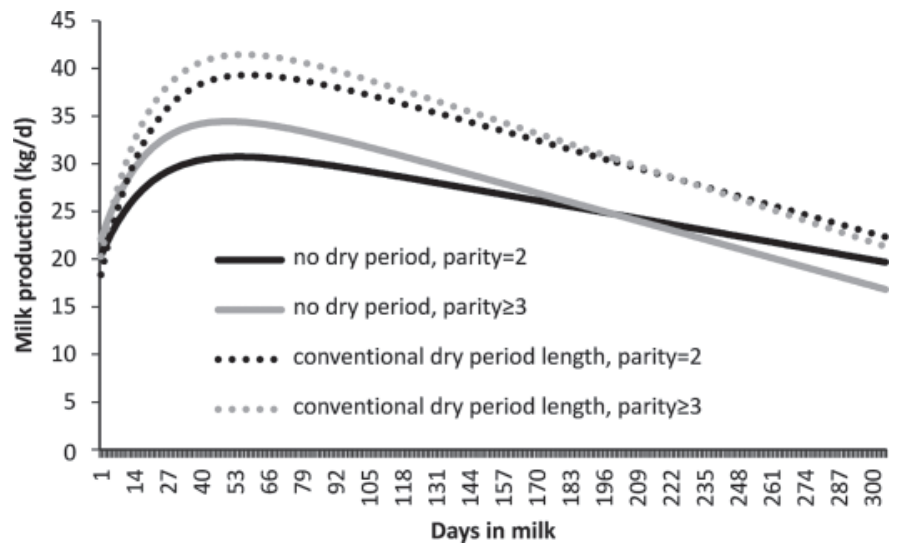

Figure 1. Estimated lactation curve (kg of milk/d) subsequent to no dry period or a conventional dry period length for cows of different parities. The curve shows the milk production of a group of cows in a single herd, in the shown parity, in a single season across DIM.

losses as low as possible. The reduction in milk production postpartum (between 12 and $32 \%$ ) was comparable with results from planned animal experiments, however. The range in milk production reduction is quite large among the 5 herds, though, and indicates, for instance, cows of herd $\mathrm{B}$ are better able to adjust to the no-DP strategy than cows of herd E. The herds differ substantially in their herd characteristics (e.g., size, milking system, breed, persistency of milk production), and therefore it is very hard to determine the specific management factors that determine the successfulness of applying the no-DP strategy. A large between-herd variation of effect on milk production was also reported by a Canadian study (Santschi et al., 2011a), comparing 13 commercial herds applying short and conventional DP length. It was mentioned that a shorter DP might not be appropriate in all management schemes.

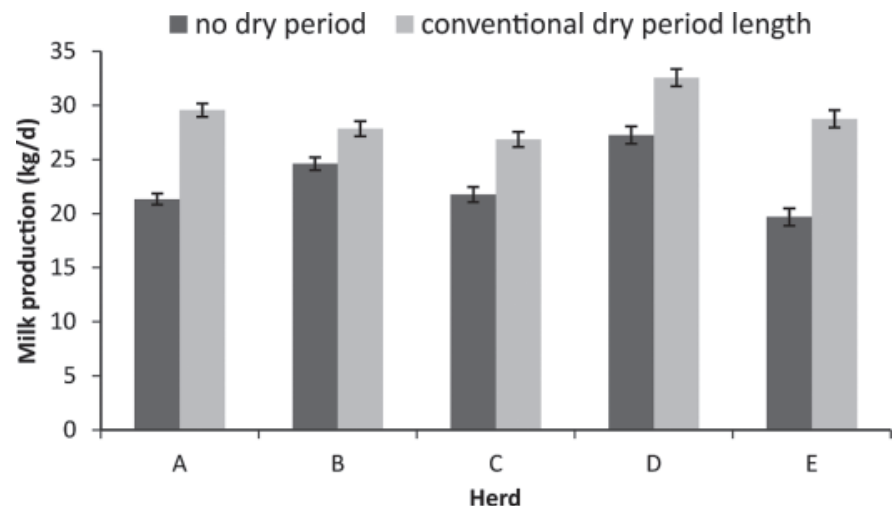

Figure 2. Estimated average daily milk yield per herd for cows with no dry period or a conventional dry period length. Values represent model predictions ( $\mathrm{LSM} \pm \mathrm{SE})$.

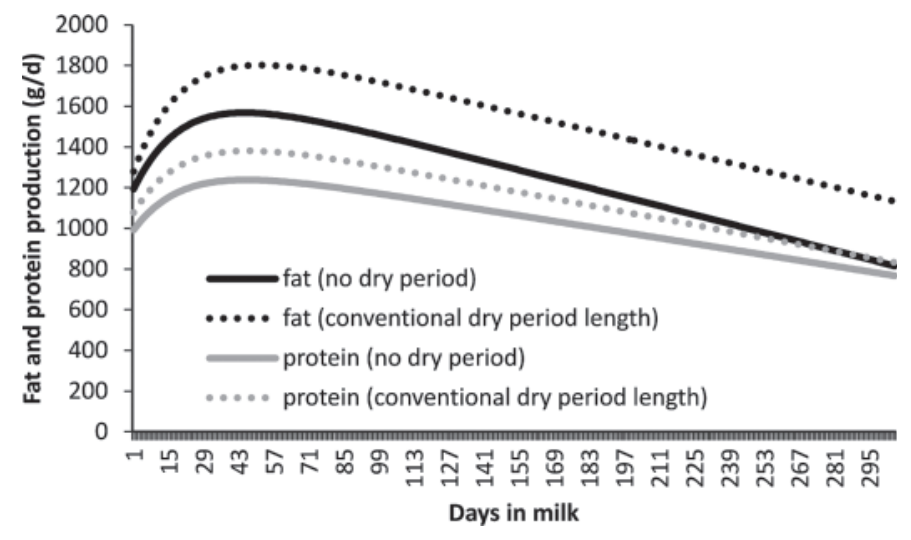

Figure 3. Estimated lactation curve (milk fat and protein; both in $\mathrm{g} / \mathrm{d}$ ) subsequent to no dry period or a conventional dry period length. The curve shows the fat and protein production of a group of cows in a single herd, in a single parity, in a single season across DIM.

In our study, milk production after no DP was estimated without taking precalving milk production into account. Therefore, the lactation curves in Figure 1 may not represent the full milk production effect. For herds applying no DP for all cows, the descriptive statistics about the last $56 \mathrm{~d}$ of the previous lactation (Table 2 ) can be used to get an impression about the additional milk yield. For instance, for second parity cows in herd A, the additional milk yield will be on average $790 \mathrm{~kg}$ $(14.1 \mathrm{~kg} \times 56 \mathrm{~d})$, and for parity $>2$ cows in herd $\mathrm{C}$ the additional milk yield will be on average $633 \mathrm{~kg}(11.3 \mathrm{~kg}$ $\times 56 \mathrm{~d}$ ). These amounts are comparable with estimates for extra milk yield prepartum, as reported previously (Rastani et al., 2005; Mantovani et al., 2010). Adding the additional milk yield precalving to the $305-\mathrm{d}$ milk production after calving resulted in a total milk production approximately $1,000 \mathrm{~kg}$ lower than that of cows with a conventional DP length. For cows with no DP, milk fat and protein percentages are higher both before and after calving. Because of the lower milk yield, the total kilograms of fat and protein produced was lower compared with a conventional DP length, which is in line with earlier studies (Rémond et al., 1997; Santschi et al., 2011a).

In this regard, all 5 herds that adopted the no-DP strategy observed a reduction in milk yield postcalving, which could not be compensated by extra milk precalving. It can therefore be questioned what drives the farmers to voluntarily implement (and continue) the no-DP strategy. The farmers of herds A through E mentioned that the decreased work load due to healthier cows and an easier cow management motivated them to apply a no-DP strategy. For instance, having only one ration, no drying-off procedure, and no group transitions decreased the work load on the herds. Some farmers also 
Table 4. Coefficient estimates $(\beta)$ of the mixed model for $\operatorname{lnSCC}$ in the lactation (1-305 DIM) subsequent to no dry period (DP) or a conventional DP length, and subsequent to different preplanned DP lengths (0-20 d dry, 21-35 d dry, and >35 d dry)

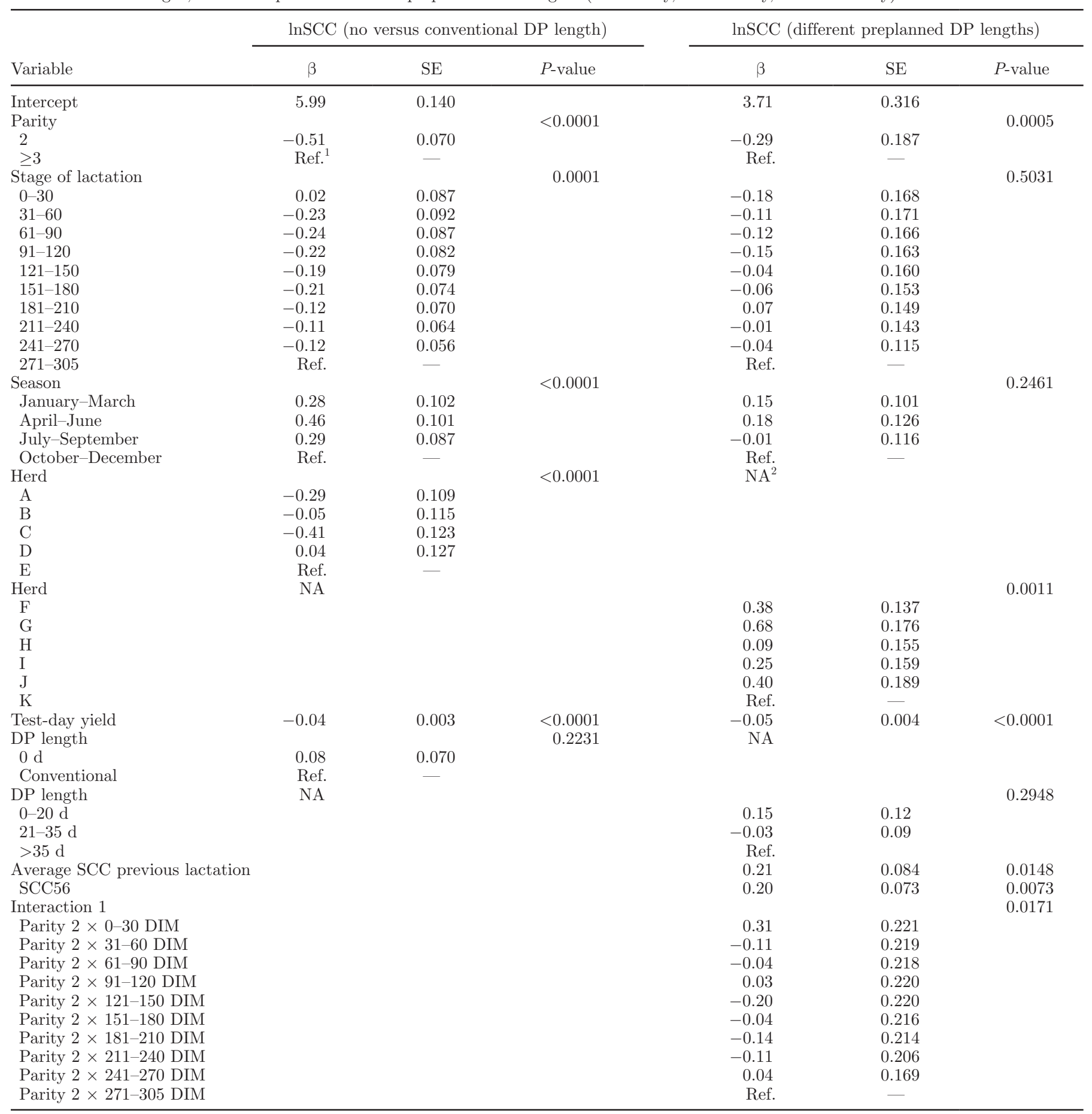

${ }^{1}$ Reference group.

${ }^{2}$ Not applicable.

mention that they experience improved health and fertility of the cows. Furthermore, 4 of the 5 farm owners mentioned that omission of the DP was accompanied by an omission of the use of preventive antibiotics at the start of the DP (farm E did not use preventive antibiotics before). Reduction in use of preventive antibiotics is not only a relevant issue in relation to a reduction in veterinary costs, but also in relation to the development 
Table 5. Milk production and composition of the previous lactation of the cows receiving different preplanned dry period (DP) lengths (values represent means)

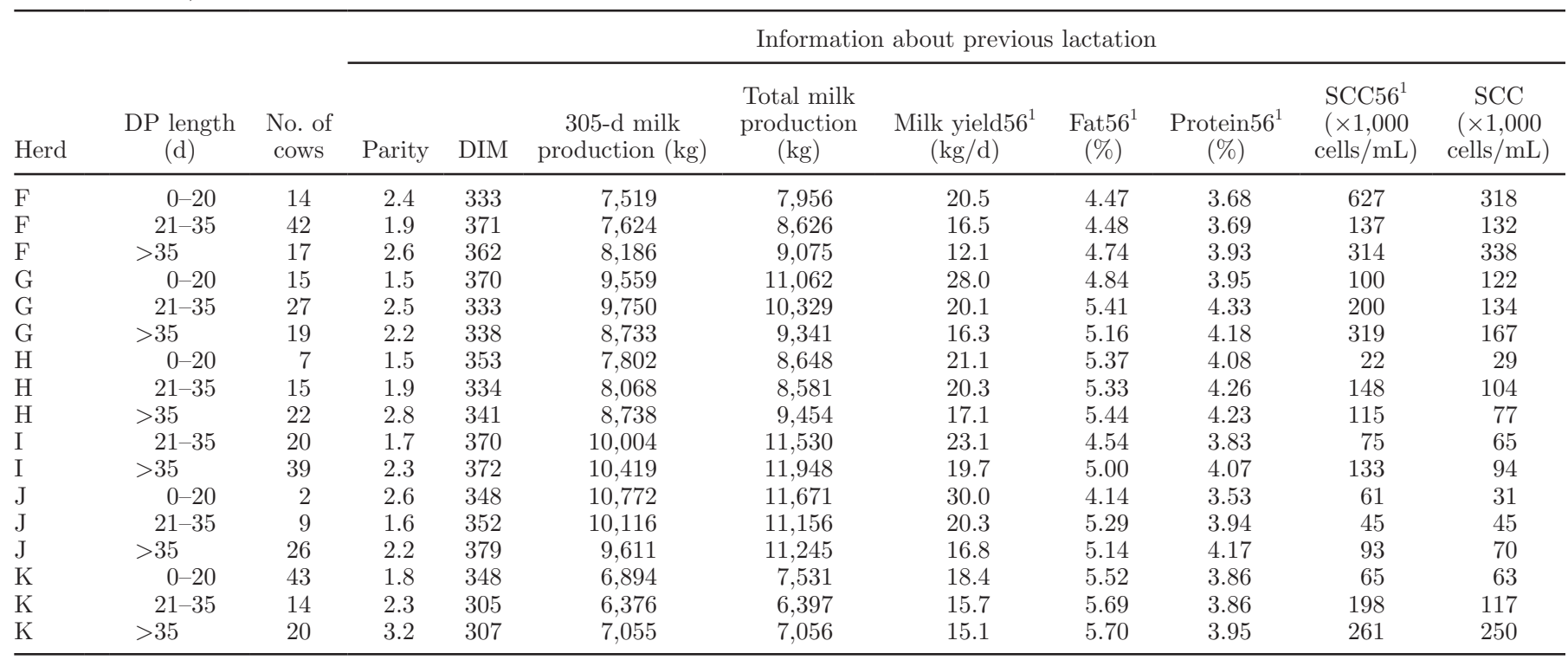

${ }^{1}$ Information from the test-day closest to $56 \mathrm{~d}$ before expected calving date.

of bacterial strains which are resistant to antibiotics, which is currently a hot topic in the Dutch dairy sector (van Werven and van Geijlswijk, 2012). Despite this reduction in labor and preventive antibiotic use, 2 herds (herd A in May 2012 and herd D in November 2011) stopped applying the no-DP strategy because of the low milk production in the subsequent lactation. Herds B, C, and E also experienced a lower milk production, but these herds are satisfied with applying the no-DP management and will continue with this strategy. For these farms it seems obvious that other factors, besides milk production, contribute to their decision to continue a no-DP strategy. Effects on labor, cow health, and antibiotic use can be hypothesized to have a role, but are not quantified in this study because of incomplete record keeping. Herds $\mathrm{F}$ through $\mathrm{K}$ all applied an individual cow approach with preplanned DP lengths, but for different reasons, such as not willing to dry-off highproducing cows or an expected reduction in health disorders after calving. More than others, high-producing cows with a low SCC received a preplanned DP length ranging from 0 to $20 \mathrm{~d}$. Different DP lengths within a herd were studied in retrospective studies (e.g., Pinedo et al., 2011). In these retrospective studies, however, it was not known if the short DP was intentional (Bachman and Schairer, 2003). Santschi et al. (2011a) also applied a preplanned DP length (35 or $60 \mathrm{~d}$ ) on commercial herds. They found that milk production was not different between DP lengths for older (parity $>2$ ) cows, but milk production was lower for young (parity 2 ) cows with a DP length of $35 \mathrm{~d}$. In our study, cows with a preplanned DP length ranging from 21 to 35 d had a lower milk production than cows with a preplanned DP length of $>35 \mathrm{~d}$, but the difference was not significant on the herds F, G, H, J, and K. Results of the current study indicate that, despite selecting cows that seemed to be best suitable for a preplanned DP length ranging from 0 to $20 \mathrm{~d}$ (high milk yield in the days before expected calving date), the milk production postcalving is low on all herds compared with cows with longer DP lengths (21-35 and >35 d dry). The farmers, however, continue to apply the DP length ranging from 0 to $20 \mathrm{~d}$, probably for other reasons, such as improved health and fertility of the cows. The SCC was not different after calving from cows with longer DP lengths, however. For other health and fertility characteristics a lack of good record prevented proper evaluation. Cows with preplanned DP lengths had additional milk before calving, but to include this amount in a corrected milk loss estimation is more difficult, as DP length was variable. A rough estimate can be obtained by using the descriptive statistics in Table 5. For instance, assuming that cows in herd F get a DP of $35 \mathrm{~d}$ instead of $56 \mathrm{~d}$ will result in an additional milk yield of maximum 347 $\mathrm{kg}(16.5 \mathrm{~kg} \times 21 \mathrm{~d})$, whereas, in herd $\mathrm{G}$, the additional milk yield for the same cows will be at most $422 \mathrm{~kg}$ (20.1 $\times 21 \mathrm{~d}$ ). Adding this amount to the 305 -d milk production postpartum of cows with a preplanned DP length ranging from 21 to $35 \mathrm{~d}$ (on average $7,587 \mathrm{~kg}$ ) will result in a milk production that is slightly lower than of the cows with a DP length $>35 \mathrm{~d}$ (on average $8,436 \mathrm{~kg}$ ).

As milk yield increases, SCC decreases in quarters without infection (Schepers et al., 1997), which may be due to a dilution effect. Green et al. (2006) inves- 
Table 6. Coefficient estimates $(\beta)$ of the mixed model for test-day milk yield $(\mathrm{kg} / \mathrm{d})$, fat production $(\mathrm{g} / \mathrm{d})$, and protein production $(\mathrm{g} / \mathrm{d})$ in the lactation (1-305 DIM) subsequent to different preplanned dry period (DP) lengths (0-20 d dry, 21-35 d dry, and >35 d dry)

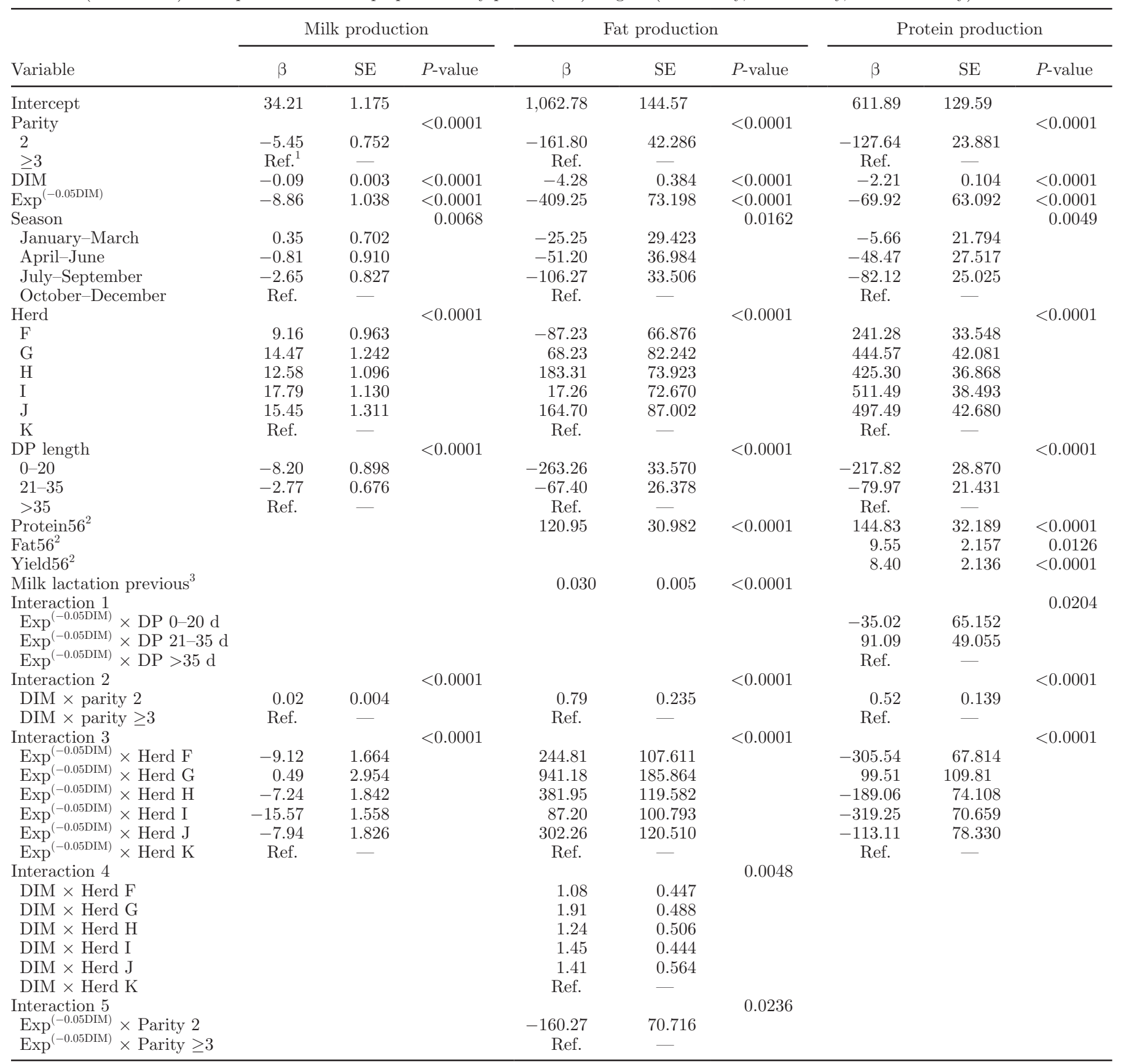

${ }^{1}$ Reference group.

${ }^{2}$ Information from the test-day closest to $56 \mathrm{~d}$ before calving.

${ }^{3}$ Total milk production in the previous lactation.

tigated the association between SCC and milk yield more thoroughly and concluded that a dilution effect of milk yield on SCC exists. Based on that observation, and the fact that milk production is lower with shorter DP lengths, test-day milk yield was included in the models to take into account the dilution effect of milk yield on SCC. The final models on SCC did not include the DP length, and therefore it can be concluded that SCC postpartum was not different for cows with different DP lengths when corrected for test-day milk yield. When not including test-day milk yield in the model, a slightly higher SCC (approximately 20,000 cells/ml) 


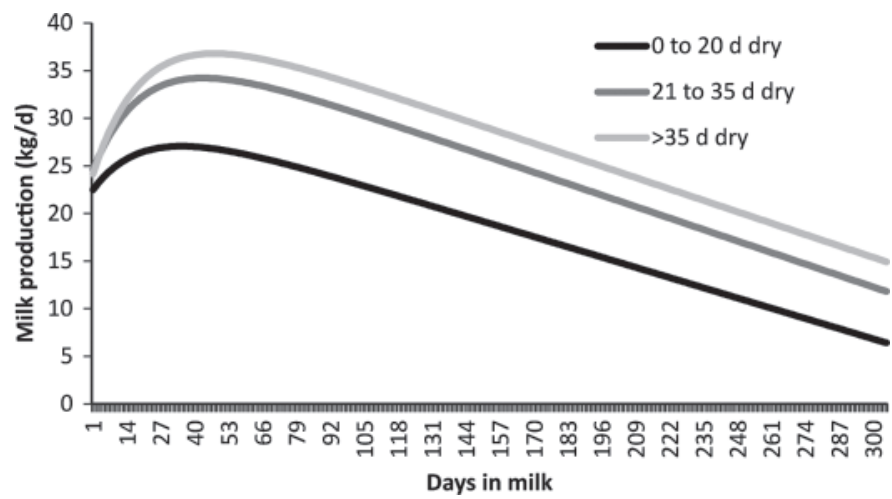

Figure 4. Estimated lactation curve ( $\mathrm{kg}$ of milk/d) subsequent to different preplanned dry period lengths. The curve shows the milk production of a group of cows in a single herd, in a single parity, in a single season across DIM.

was observed for cows with no DP compared with cows with a conventional DP length (results not shown). This indicates that a dilution effect of milk production on test-day SCC was also likely present in our study. Previous studies reported also no difference in SCC for cows with different DP lengths, but a possible dilution effect was not taken into account (Annen et al., 2004; Church et al., 2008; Watters et al., 2008). It would also be interesting to compare the difference in SCC from just before calving to the first SCC record after calving. Preliminary results of our study (results not shown) show that cows with a DP length of $>35 \mathrm{~d}$ had a lower SCC after calving compared with the last test-day record from before calving. Cows with a DP length of 0 to $20 \mathrm{~d}$ have a higher SCC after calving compared with the last test-day records before calving. More information and a more thorough analysis will be needed to investigate the number of new infections or cure rates after different DP lengths.

An economic evaluation will give more insight in the consequences of applying no DP and cow-specific preplanned DP lengths. The application of the preplanned DP lengths of $>21 \mathrm{~d}$ might be beneficial because of the relative small reduction in milk production. Previously, 2 studies investigated the economic consequences of a shorter DP compared with a conventional DP length. Sørensen et al. (1993) simulated different preplanned DP lengths and concluded that a DP of 7 wk was preferable under most circumstances. Based on data from 13 commercial Canadian herds, Santschi et al. (2011b) concluded that an average herd would benefit from switching from a conventional length of approximately $8 \mathrm{wk}$ to a DP of $35 \mathrm{~d}$. This result was mainly due to additional milk sold, decreased replacement rate, and a lower calving interval. To our knowledge, the economic consequence of the application of no DP has not been studied. For a complete economic evaluation of the ap-

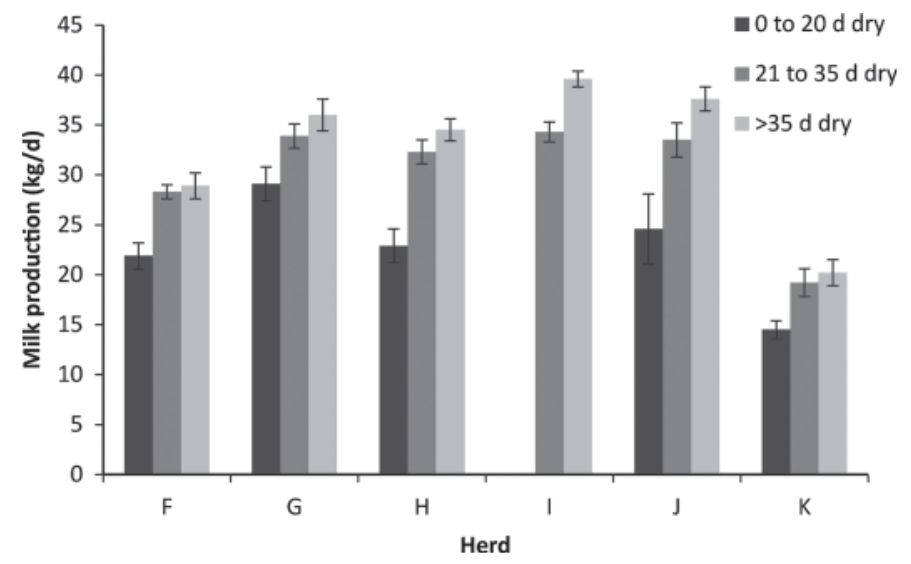

Figure 5. Estimated daily milk yield per herd for cows with different preplanned dry period lengths. Values represent model predictions $(\mathrm{LSM} \pm \mathrm{SE})$.

plication of no or short DP, the effect on milk production, health, fertility, longevity, and labor requirements will need to be taken into account. Results on milk production from our study, and also from other studies (Annen et al., 2004; Rastani et al., 2005; Watters et al., 2008), can be used for such an evaluation. Preferably,
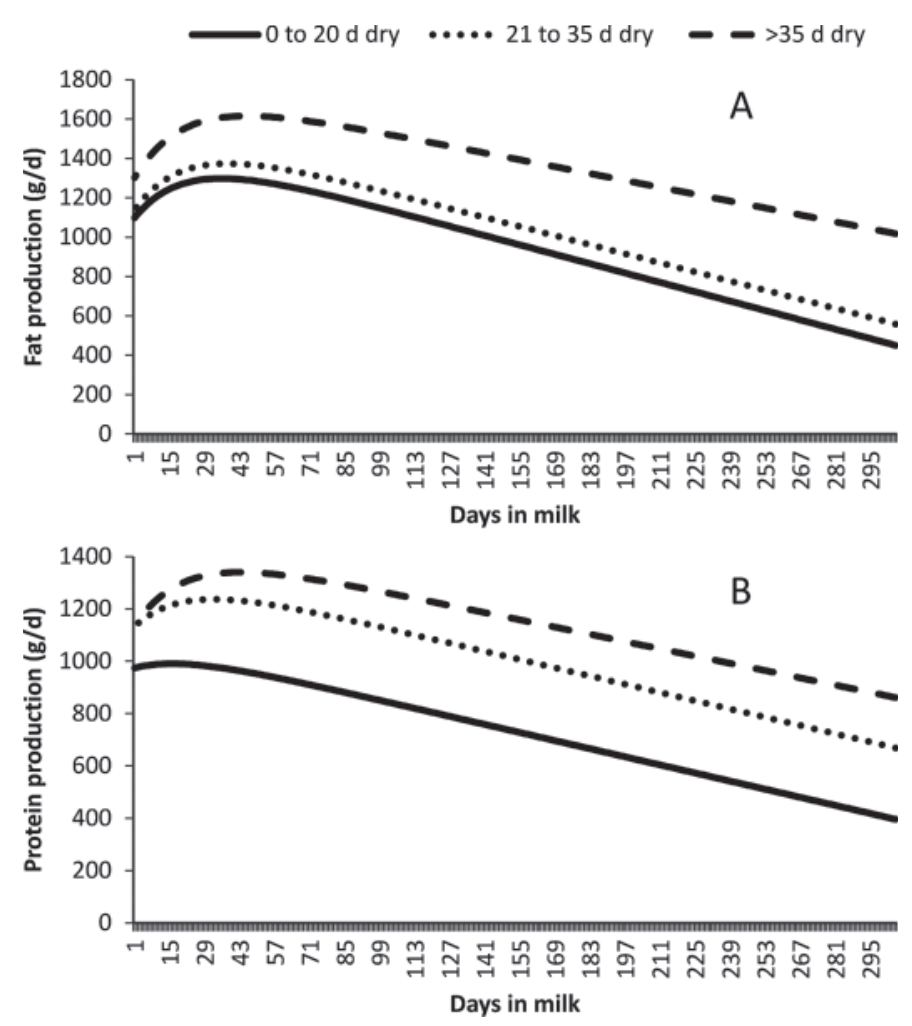

Figure 6. Estimated lactation curve for milk fat (A) and protein (B; both in $\mathrm{g} / \mathrm{d}$ ) subsequent to different preplanned dry period lengths. The curves show the fat and protein production of a group of cows in a single herd, in a single parity, in a single season across DIM. 
the effect of applying no or short DP for consecutive lactations on milk production should be investigated. Previously, it was reported that omission of the DP over several consecutive lactations is difficult (Rémond et al., 1997). Several studies mentioned that no DP and a shorter DP resulted in better fertility performance (Gümen et al., 2005; Watters et al., 2009; Santschi et al., 2011c) and an improved metabolism (de Feu et al., 2009; Schlamberger et al., 2010). These effects need to be taken into account as well in an economic evaluation. The effect of no or a shorter DP on longevity or replacement rate needs to be studied across several years, and will be therefore be difficult to measure.

The drive for farmers to omit or shorten the DP differed between farms applying a no-DP strategy for the whole herd and farms which apply a preplanned DP strategy. Whereas farms choosing a no-DP strategy for the whole herd look for a management adjustment for their whole herd to ease cow management, farms applying a preplanned DP strategy choose an individual cow approach based on cow characteristics, such as persistency, milk yield, and SCC. This second approach resulted in a no-DP strategy for the young cows, which had a higher milk yield precalving and lower SCC. It can be questioned if the farmers reached what they were aiming for in the long term, as the young cows (parity 2) are suggested to have a greater reduction in milk yield postcalving when the DP is omitted compared with older cows (Annen et al., 2004). This indicates possibilities for further optimization of the preplanned DP strategy. Moreover, to our knowledge little is known about management adjustments in relation to the noor shortened-DP strategy. It can be hypothesized that milk yield losses could be reduced and health and fertility effects amplified by optimizing dairy cow rations in late and early lactation, using (preventive) antibiotics, and implementing insemination strategies for cows with a shortened or no DP.

\section{CONCLUSIONS}

The application of no DP for all cows in 5 commercial Dutch dairy herds resulted in a reduction in milk production postpartum (1-305 DIM) between 3.2 and 9.1 $\mathrm{kg} / \mathrm{d}$, which is a reduction of 12 and $32 \%$, respectively. Large between-herd variation in milk production effects of a no-DP strategy indicated that some herds are better able to adjust to the no-DP strategy than others. An individual cow approach with different preplanned DP lengths on 6 other commercial Dutch dairy herds resulted in lowest milk production for cows with a DP of 0 to $20 \mathrm{~d}$, compared with cows with a DP $>35 \mathrm{~d}$. When correcting for the reduction in milk yield, no difference in SCC postpartum was found for cows with different
DP lengths on any of the 11 herds. For a complete economic evaluation of a no-DP or cow-specific preplanned DP length strategy more information is essential not only on hypothesized health and fertility benefits, but also on labor requirements and milk production effects during successive lactations.

\section{ACKNOWLEDGMENTS}

The authors thank the participating farmers for providing data. This research is financed by the Dutch Dairy Board (Zoetermeer, the Netherlands), the Dutch Product Board Animal Feed (Zoetermeer, the Netherlands), and CRV (Arnhem, the Netherlands).

\section{REFERENCES}

Andersen, J. B., T. G. Madsen, T. Larsen, K. L. Ingvartsen, and M. O. Nielsen. 2005. The effects of dry period versus continuous lactation on metabolic status and performance in periparturient cows. J. Dairy Sci. 88:3530-3541.

Annen, E. L., R. J. Collier, M. A. McGuire, J. L. Vicini, J. M. Ballam, and M. J. Lormore. 2004. Effect of modified dry period lengths and bovine somatotropin on yield and composition of milk from dairy cows. J. Dairy Sci. 87:3746-3761.

Bachman, K. C., and M. L. Schairer. 2003. Invited review: Bovine studies on optimal lengths of dry periods. J. Dairy Sci. 86:30273037.

Butler, W. R. 2003. Energy balance relationships with follicular development, ovulation and fertility in postpartum dairy cows. Livest. Prod. Sci. 83:211-218.

Church, G. T., L. K. Fox, C. T. Gaskins, D. D. Hancock, and J. M. Gay. 2008. The effect of a shortened dry period on intramammary infections during the subsequent lactation. J. Dairy Sci. 91:4219-4225.

Collard, B. L., P. J. Boettcher, J. C. M. Dekkers, D. Petitclerc, and L. R. Schaeffer. 2000. Relationships between energy balance and health traits of dairy cattle in early lactation. J. Dairy Sci. $83: 2683-2690$.

de Feu, M. A., A. C. O. Evans, P. Lonergan, and S. T. Butler. 2009. The effect of dry period duration and dietary energy density on milk production, bioenergetic status, and postpartum ovarian function in Holstein-Friesian dairy cows. J. Dairy Sci. 92:6011-6022.

Dohoo, I. R., S. W. Martin, and H. Stryhn. 2003. Veterinary Epidemiological Research. Atlantic Veterinary College Inc., Charlottetown, Prince Edward Island, Canada.

Green, L. E., Y. H. Schukken, and M. J. Green. 2006. On distinguishing cause and consequence: Do high somatic cell counts lead to lower milk yield or does high milk yield lead to lower somatic cell count? Prev. Vet. Med. 76:74-89.

Grummer, R. R. 1993. Etiology of lipid-related metabolic disorders in periparturient dairy cows. J. Dairy Sci. 76:3882-3896.

Grummer, R.R., and R.R. Rastani. 2004. Why re-evaluate dry period length? J. Dairy Sci. 87(E. Suppl.):E77-E85.

Gulay, M. S., M. J. Hayen, K. C. Bachman, T. Belloso, M. Liboni, and H. H. Head. 2003. Milk production and feed intake of Holstein cows given short (30-d) or normal (60-d) dry periods. J. Dairy Sci. 86:2030-2038.

Gümen, A., R. R. Rastani, R. R. Grummer, and M. C. Wiltbank. 2005. Reduced dry periods and varying prepartum diets alter postpartum ovulation and reproductive measures. J. Dairy Sci. 88:2401-2411.

Klusmeyer, T. H., A. C. Fitzgerald, A. C. Fabellar, J. M. Ballam, R. A. Cady, and J. L. Vicini. 2009. Effect of recombinant bovine somatotropin and a shortened or no dry period on the performance of lactating dairy cows. J. Dairy Sci. 92:5503-5511. 
Mantovani, R., L. Marinelli, L. Bailoni, G. Gabai, and G. Bittante. 2010. Omission of dry period and effects on the subsequent lactation curve and on milk quality around calving in Italian Holstein cows. Ital. J. Anim. Sci. 9:101-108.

Pezeshki, A., J. Mehrzad, G. R. Ghorbani, H. R. Rahmani, R. J. Collier, and C. Burvenich. 2007. Effects of short dry periods on performance and metabolic status in Holstein dairy cows. J. Dairy Sci. 90:5531-5541.

Pinedo, P., C. Risco, and P. Melendez. 2011. A retrospective study on the association between different lengths of the dry period and subclinical mastitis, milk yield, reproductive performance, and culling in Chilean dairy cows. J. Dairy Sci. 94:106-115.

Rastani, R. R., R. R. Grummer, S. J. Bertics, A. Gumen, M. C. Wiltbank, D. G. Mashek, and M. C. Schwab. 2005. Reducing dry period length to simplify feeding transition cows: Milk production, energy balance, and metabolic profiles. J. Dairy Sci. 88:1004-1014.

Rémond, B., J. Rouel, N. Pinson, and S. Jabet. 1997. An attempt to omit the dry period over three consecutive lactations in dairy cows. Ann. Zootech. 46:399-408.

Santschi, D. E., D. M. Lefebvre, R. I. Cue, C. L. Girard, and D. Pellerin. 2011a. Complete-lactation milk and component yields following a short (35-d) or a conventional (60-d) dry period management strategy in commercial Holstein herds. J. Dairy Sci. 94:2302-2311.

Santschi, D. E., D. M. Lefebvre, R. I. Cue, C. L. Girard, and D. Pellerin. 2011b. Economic effect of short (35-d) compared with conventional (60-d) dry period management in commercial Canadian Holstein herds. J. Dairy Sci. 94:4734-4743.

Santschi, D. E., D. M. Lefebvre, R. I. Cue, C. L. Girard, and D. Pellerin. 2011c. Incidence of metabolic disorders and reproductive performance following a short (35-d) or conventional (60-d) dry period management in commercial Holstein herds. J. Dairy Sci. 94:3322-3330.

Schepers, A. J., T. J. G. M. Lam, Y. H. Schukken, J. B. M. Wilmink, and W. J. A. Hanekamp. 1997. Estimation of variance components for somatic cell counts to determine thresholds for uninfected quarters. J. Dairy Sci. 80:1833-1840.

Schlamberger, G., S. Wiedemann, E. Viturro, H. H. D. Meyer, and M. Kaske. 2010. Effects of continuous milking during the dry period or once daily milking in the first 4 weeks of lactation on metabolism and productivity of dairy cows. J. Dairy Sci. 93:2471-2485.

Sørensen. J. T., C. Enevoldsen, and T. Kristensen. 1993. Effects of different dry period lengths on production and economy in the dairy herd estimated by stochastic simulation. Livest. Prod. Sci. 33:77-90.

van Werven, T., and I. M. van Geijlswijk. 2012. Use of antibiotics in the Netherlands: How to achieve a reduction of 50\%. Pages 9-15 in Proc. National Mastitis Council Annu. Mtg. National Mastitis Council, Madison, WI..

Watters, R. D., J. N. Guenther, A. E. Brickner, R. R. Rastani, P. M. Crump, P. W. Clark, and R. R. Grummer. 2008. Effects of dry period length on milk production and health of dairy cattle. J. Dairy Sci. 91:2595-2603.

Watters, R. D., M. C. Wiltbank, J. N. Guenther, A. E. Brickner, R. R. Rastani, P. M. Fricke, and R. R. Grummer. 2009. Effect of dry period length on reproduction during the subsequent lactation. J. Dairy Sci. 92:3081-3090.

Wilmink, J. B. M. 1987. Adjustment of test-day milk, fat and protein yield for age, season and stage of lactation. Livest. Prod. Sci. $16: 335-348$. 